\title{
The establishment of a bank of stored clinical bone marrow stromal cell products
}

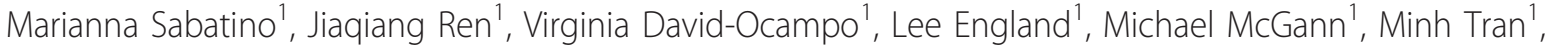 \\ Sergei A Kuznetsov², Hanh Khuu', Arun Balakumaran², Harvey G Klein ${ }^{1}$, Pamela G Robey ${ }^{2}$ and David F Stroncek ${ }^{1 *}$
}

\begin{abstract}
Background: Bone marrow stromal cells (BMSCs) are being used to treat a variety of conditions. For many applications a supply of cryopreserved products that can be used for acute therapy is needed. The establishment of a bank of BMSC products from healthy third party donors is described.
\end{abstract}

Methods: The recruitment of healthy subjects willing to donate marrow for BMSC production and the Good Manufacturing Practices (GMP) used for assessing potential donors, collecting marrow, culturing BMSCs and BMSC cryopreservation are described.

Results: Seventeen subjects were enrolled in our marrow collection protocol for BMSC production. Six of the 17 subjects were found to be ineligible during the donor screening process and one became ill and their donation was cancelled. Approximately $12 \mathrm{ml}$ of marrow was aspirated from one posterior iliac crest of 10 donors; one donor donated twice. The BMSCs were initially cultured in T-75 flasks and then expanded for three passages in multilayer cell factories. The final BMSC product was packaged into units of $100 \times 10^{6}$ viable cells, cryopreserved and stored in a vapor phase liquid nitrogen tank under continuous monitoring. BMSC products meeting all lot release criteria were obtained from 8 of the 11 marrow collections. The rate of growth of the primary cultures was similar for all products except those generated from the two oldest donors. One lot did not meet the criteria for final release; its CD34 antigen expression was greater than the cut off set at 5\%. The mean number of BMSC units obtained from each donor was 17 and ranged from 3 to 40.

Conclusions: The production of large numbers of BMSCs from bone marrow aspirates of healthy donors is feasible, but is limited by the high number of donors that did not meet eligibility criteria and products that did not meet lot release criteria.

\section{Background}

Bone marrow-derived stromal cells (BMSCs) are adult multipotent cells that can be isolated from bone marrow $[1,2]$. For their multitude of actions they represent a very attractive tool in cellular therapies; osteogenesis imperfecta [3,4], acute and chronic graft versus host disease (GVHD) [5-11], inflammatory bowel disease [12], ischemic heart disease [13], non-healing ulcers [14], ischemic stroke [15], multiple sclerosis [16], amyotrophic lateral sclerosis [16,17], Parkinson's disease [18], and spinal cord injury [19]. These are only a few

\footnotetext{
* Correspondence: dstroncek@cc.nih.gov

'Department of Transfusion Medicine, Clinical Center, National Institutes of Health, Building 10, Room 1C711, Bethesda, MD 20892-1184, USA Full list of author information is available at the end of the article
}

examples of their application in phase I, II and III clinical trials.

Traditionally, BMSCs are derived from marrow aspirates or marrow tissue associated with surgical bone specimens or bone biopsies, but the percentage of marrow cells which are BMSCs is very low; between 0.01$0.001 \%$. For in vivo use, BMSCs must be expanded to reach adequate numbers for therapeutic doses. For this reason cell processing facilities have established processes for the large scale production of BMSCs for autologous use when long-term BMSC engraftment and differentiation may be required and the use of HLAmatched BMSCs is needed [20-22]. However, when long-term survival of BMSCs is not necessary, the use of BMSCs without regard for HLA-matching has been shown to be effective. The effectiveness of third party

\section{Biomed Central}


donor BMSCs is likely due to the modulation of the host immune and inflammatory response by cytokines and growth factors released by BMSCs. For these applications banks of third party human BMSCs have been created where BMSCs are isolated, expanded ex vivo over several weeks, cryopreserved and finally thawed and administered to patients determined eligible for specific treatments $[5,6,10]$.

In 2008 the NIH Bone Marrow Stromal Cell Transplantation Center (BMSC TC) was established. The aim of the center was to create the infrastructure to manufacture clinical grade human BMSCs and to facilitate the use of ex vivo expanded BMSCs for the treatment of patients with a variety of human diseases and disorders within the Clinical Center. In this paper we report the manufacturing process we have optimized and validated to produce "clinical grade" BMSCs in support of the BMSC TC activities. The processes used to screen donors, collect marrow, and to produce and cryopreserve BMSCs are described as well as the results of the first 11 full scale BMSC production runs in our GMP facility.

\section{Methods}

\section{Donor eligibility and donor screening process}

All donors were required to meet Food and Drug Administration (FDA) and AABB (formally the American Association of Blood Banks) criteria for cellular therapy donors. A protocol for the donation of marrow for BMSC production was created, posted on the NIH website and registered in clinicaltrials.gov with the identification number NCT01071577. Potential volunteers made the initial contact with the Department of Transfusion Medicine (DTM, NIH) by phone or email and the protocol procedures and risks were explained. Demographic information, an abbreviated questionnaire for determination of risk factors for transmissible infections including recent travel outside of the USA or Canada and an abbreviated medical history were obtained. If no factors were identified that would make him/her ineligible, they were then invited to make a follow-up appointment in the Donor Center for a complete donor eligibility evaluation. At this point a NIH healthy volunteer consent was obtained and a unique NIH medical record number (MRN) assigned and legal identification verified to insure correct patient identity and age since the donor's age must be greater than or equal to 18 years. In a private setting a thorough explanation of the protocol including risks was completed, time was allowed for donor questions, and then informed consent obtained. Three forms, AABB donor education materials, medical deferral list, and foreign travel information sheet (a list of medications that cause deferral and a list of the countries in Europe and the United Kingdom where travel or residency can result in a permanent deferral from donating due to variant Creutzfeldt-Jakob disease (vCJD) risk) were reviewed. An FDA approved standardized screening questionnaire for cellular therapy products was administered verbally by trained DTM staff and answers were recorded on paper. This questionnaire documents an abbreviated medical history and screens for risk factors that identify a donor's potential for exposure to HIV, hepatitis, and other viral infections as well as exposure to malaria, vCJD and other diseases. This paper became part of the official record that is kept in a secure folder in a locked room.

\section{Donor testing}

A brief physical exam was performed; blood samples were collected and tested for markers of transfusion transmitted diseases (TTD), complete blood counts $(\mathrm{CBC})$, coagulation assays, HLA type, ABO blood group and pregnancy where appropriate. Donors were tested for anti-HIV-1/2, hepatitis B virus surface antigen (HBs $\mathrm{Ag}$ ), anti-hepatitis $\mathrm{B}$ virus core antigen (anti-HBC), antihepatitis $\mathrm{C}$ virus (anti-HCV), RPR-Treponema pallidum (syphilis), anti-HTLV-1, anti-HTLV-2, cytomegalovirus IgG, IgM antibody (anti-CMV), anti-T. Cruzi (Chagas), HIV-1/HCV/HBV nucleic acid testing (NAT) and West Nile Virus NAT. Donors were also tested for $\mathrm{CBC}$ with differential white cell count, prothrombin time (PT), partial thromboplastin time (PTT) and HLA- A, B, C and DR/DQ. With the exception of the RPR, the TTD tests were sent to an outside FDA approved laboratory for donor screening assays. The donor must have a platelet count $>150 \times 10^{9} / \mathrm{L}$, absolute neutrophil count $>$ $1.0 \times 10^{9} / \mathrm{L}$ and hemoglobin $>11.5 \mathrm{~g} / \mathrm{dL}$ for African or African American women, > $12.0 \mathrm{~g} / \mathrm{dL}$ for all other women and $12.5 \mathrm{~g} / \mathrm{dL}$ for all men and the PT and PTT must be within normal limits. The results of the TTD, $\mathrm{CBC}, \mathrm{PT}, \mathrm{PTT}$ and pregnancy assays were used to determine donor eligibility while the results of $\mathrm{ABO}$ blood group and HLA type were used for identity testing of the product.

If the potential donor met the eligibility criteria, the marrow aspiration was scheduled. This was done within 30 days of the pre-screening visit according to AABB and FDA standards.

\section{Bone marrow collection}

On the day of marrow aspiration, the donors first reported to the Blood Donor Center and were registered into our center's Blood Bank Computer System (BBCS, Blood Bank Computer Systems Inc, Auburn, Washington), a password protected data management system that assigns each donor a unique donor identification number and tracts the results of donor screening via a Self Reporting Questionnaire (SRQ) as well as physical examination, $\mathrm{ABO}$ grouping and transfusion transmitted 
disease tests. After the donor was registered an abbreviated physical exam was repeated and another blood sample was collected for TTD testing and ABO grouping as previously reported.

The donor was then taken to a hospital procedure room. First, the risks of bone marrow aspiration were reviewed and a surgical consent was signed by each donor. As required by the Joint Commission on Accreditation of Healthcare Organizations (JCAHO), a "time out" was taken to verify donor identity and donor understanding of the procedure to be performed. Bone marrow aspirates were collected according to the standard procedure in use at the NIH Clinical Center; the protocol allows for bilateral collection, but to date unilateral aspirates only have been collected.

A $1 \mathrm{~mL}$ aliquot of bone marrow at each collection was evaluated by a hematopathology medical technologist in the Department of Laboratory Medicine for the presence of bone spicules as a measurement of aspirate quality; a marrow smear and peripheral blood smear is reviewed as well for normal trilineage hematopoiesis. A limited volume of marrow was aspirated (max $12 \mathrm{~mL}$ ) to avoid excessive dilution with peripheral blood, and collected in multiple $3 \mathrm{~mL}$ Bone Marrow Prep Syringes (Pharmacy Department, CC, NIH) containing DMEM, heparin and gentamicin. Syringes were properly labeled and transported at room temperature to the CPS laboratory.

\section{Marrow processing and BMSC production Receipt of marrow by the cell processing laboratory}

The marrow aspirate was received by trained cell processing laboratory staff. At the time of receipt each syringe was inspected and its appearance, identifiers and time of receipt was documented. The samples were processed immediately, but the laboratory's procedures allow samples to be stored at $2-8^{\circ} \mathrm{C}$ for a maximum of 4 $\mathrm{h}$ prior to processing.

\section{Overview of processing}

The BMSCs were initially cultured in T-75 flasks. They were then expanded for three passages in multilayer cell factories. At the completion of the processing the BMSCs from the final harvest were packaged into units of 100 million viable cells, cryopreserved and stored in the vapor phase of a liquid nitrogen storage tank.

\section{Marrow aspirate receipt and evaluation}

After receipt, the aspirates were pooled into a $50 \mathrm{~mL}$ conical tube (BD Falcon, BD Biosciences, Bedford, MA) and total volume estimated and diluted up to 3.5 times by adding Bone Marrow Stromal Cell Culture Media (BMSC CM) which consisted of: alpha MEM (Lonza, Walkersville, MD) supplemented with 20\% lot-selected US origin Defined Fetal Bovine Serum (FBS) (Hyclone Laboratories, Inc., Logan, UT) and gentamicin sulfate
(10 mcg/mL) (Gentamicin, injection, UPS, AAPP Pharmaceuticals, LCC, Schaumburg, IL). A single cell suspension was prepared; cells were passed through an 18 ga spinal needle (18 ga, 3.5 in., Monoject, Covidien, Mansfield, MA) twice and then through a 20 ga spinal needle (BD Spinal Needle, BD Medical, Franklin Lakes, $\mathrm{NJ}$ ) twice and resuspended in 20 to $30 \mathrm{~mL}$ with BMSC CM.

A $1 \mathrm{~mL}$ aliquot of solution was removed for cell counts (Celldyne 3700, Abbott Laboratories Inc., Abbot Park, IL), and analysis by flow cytometry for CD3 and CD34 content and viability using 7AAD (BD FACSCanto, BD Biosciences, San Jose, CA) (Table 1). An inprocess control was set at this point and the aspirate was discarded if the total nucleated cell (TNC) count was $<20 \times 10^{6}$. Colony Formation Efficiency (CFE) was performed as previously described [23] as a quality measure of the starting material. The CFE and CD34+ cell counts were obtained for retrospective analysis, but were not used to qualify the starting material.

\section{Initial growth of BMSCs}

The BMSCs were initially grown in T-75 flasks $\left(75 \mathrm{~cm}^{2}\right.$ flask, canted neck, nonpyrogenic, sterile polystyrene, Corning Incorporated, Corning, NY). The flasks were seeded at a cell density of 2 to $3 \times 10^{5}$ cells per $\mathrm{cm}^{2}$ of surface area and a final volume of $20 \mathrm{~mL}$ BMSC CM. The flasks were incubated at $37^{\circ} \mathrm{C}$ in $5 \% \mathrm{CO}_{2}$ and $90 \pm$ $5 \%$ humidity. Thirty percent of the flasks were used to assess colony formation and confluence periodically during the culture by evaluating $40 \%$ of the surface of the bottom of the flasks.

On day 1 of culture, $24 \mathrm{~h}$ after plating the cells, supernatants containing non-adherent cells were removed through complete media exchange and the flasks reincubated at $37^{\circ} \mathrm{C}$ in $5 \% \mathrm{CO}_{2}$ and $90 \pm 5 \%$ humidity. Thereafter, complete media exchange was performed every 3 days. On day 7 the flasks assigned for colony

\section{Table 1 BMSC lot release criteria}

\begin{tabular}{lll}
\hline Test & Method & Criteria \\
\hline CD73 & Flow cytometry & $\geq 80 \%$ reactive cells \\
CD90 & Flow cytometry & $\geq 80 \%$ reactive cells \\
CD105 & Flow cytometry & $\geq 80 \%$ reactive cells \\
CD146 & Flow cytometry & $\geq 60 \%$ reactive cells \\
CD34 & Flow cytometry & $\leq 5 \%$ reactive cells \\
CD45 & Flow cytometry & $\leq 5 \%$ reactive cells \\
CD14 & Flow cytometry & $\leq 5 \%$ reactive cells \\
CD11b & Flow cytometry & $\leq 5 \%$ reactive cells \\
Viability & Trypan blue & $\geq 70 \%$ \\
Sterility & Bactec Plus, aerobic and & No growth after 14 \\
& anaerobic & days \\
Mycoplasma & PCR & Negative \\
Endotoxin & Limulus Amebocyte Lysate (LAL) & $<5.0$ EU/mL \\
\hline
\end{tabular}


formation assessment were inspected using an inverted microscope and under $25 \times$ magnification. If no colonies were detected, the cultures were discontinued; otherwise, the cultures were maintained. Beginning on day 10 the number of colonies with more than 50 cells and > $70 \%$ confluence and with more than 50 cells and $<70 \%$ confluence was recorded. If more than half the colonies were $>70 \%$ confluent, the cells were harvested. If less than half the colonies were > 70\% confluent, then BMSC CM media was replaced and the process repeated the next day. Colony counting and confluence assessment continued daily until the harvest criteria were met or the culture reached Day 13; the cultures were terminated if the criteria were not met.

Primary culture was harvested by trypsinization. We used commercially available recombinant trypsin (TryPLE Express Invitrogen, CA) to limit the usage of animal derived reagents. An aliquot of the final harvested cells was assessed for manual cell counts and viability by the trypan blue exclusion method and sterility (BD BACTEC plus + aerobic/F and BD BACTEC plus + anaerobic/F, Becton Dickenson and Company, Sparks, $\mathrm{MD})$. The BMSCs were also evaluated by flow cytometry for the expression of BMSC surface markers according to the ISCT panel. The culture was discontinued if viability was $<70 \%$ or sterility testing was positive. The isolated BMSCs were designated passage 1 cells.

\section{In vitro expansion}

Passage 1 BMSCs were seeded in 2-layer cell factories (Cell Factory, easy fill 2-trays, Nunc A/S, Roskilde, Denmark) at a cell density of 2,500-4,000 cells $/ \mathrm{cm}^{2}$. The plating density was based on published data. A maximum of 4 culture vessels were seeded for each processing event due to the maximum capacity of the GMP processing suite dedicated to BMSCs production. To facilitate the handling of cultures a peristaltic pump using an adaptor specifically designed was used for media and cell loading (Fluid transfer tube set, Baxa Corporation, Englewood, CO). The media levels were equalized on the two layers and the cell factories were incubated at $37^{\circ} \mathrm{C}$ with $5 \% \mathrm{CO}_{2}$ and $90 \pm 5 \%$ humidity.

On day 3 complete media exchange was performed. Cells were harvested on day 5 or 6 once the culture met the criteria defined as $70 \%$ confluence. Culture was discarded if confluence was $<70 \%$ on day 6 . Harvest was performed as for flasks using TryPLE express. If the volume of the cells recovered was less than or equal to $1200 \mathrm{~mL}$, it was reduced using a floor model centrifuge (Sorvall RC3, DuPont, Newtown, CT) set at $406 \mathrm{~g}$ for 10 mins. If the volume was $>1200 \mathrm{~mL}$ a cell washer (Cobe 2991 cell processor, Caridian BCT, Lakewood, CO) was used. The passage 2 BMSCs were resuspended in $50 \mathrm{~mL}$ of BMSC CM and $0.5 \mathrm{~mL}$ was removed for manual cell counts and viability assessment using trypan blue staining. The culture at this point was terminated if the viability was $<70 \%$.

\section{BMSC passage 2 culture}

Passage 2 BMSCs were seeded in 10-layer cell factories (Cell Factory, easy fill 10-trays, Nunc A/S) at a cell density of 2,500-4,000 cells $/ \mathrm{cm}^{2}$. After measuring the number of BMSCs harvested, the number of 10-layer cell factories, each of which has a surface area of $6,300 \mathrm{~cm}^{2}$, that could be seeded and the number of cells to place in each cell factory was calculated. Our protocol permits a maximum of four 10-layer cell factories to be seeded with passage 2 cells. Approximately $20 \times 10^{6}$ per 10 layer cell factory in a final volume of $2.5 \mathrm{~L}$ BMSC CM per container was loaded using the automatic system described above. The media levels were equalized and cell factories incubated at $37^{\circ} \mathrm{C}$ with $5 \% \mathrm{CO}_{2}$ and $90 \pm$ $5 \%$ humidity. On culture day 3 , a complete media exchange was performed, and a volume of $2.5 \mathrm{~L}$ fresh BMSC CM was added. The cell harvest was planned for day 5 or 6 according to the degree of cell confluence. The culture was discontinued if cell confluence was < $70 \%$ on day 6.

Harvested passage 3 cells were assessed for cell count and viability. The harvested BMSCs were concentrated using a cell washer (Cobe 2991 Cell Processor) and resuspended in $100 \mathrm{~mL}$ of $\mathrm{BMSC} \mathrm{CM}$.

\section{BMSC passage 3 culture}

For passage 3 culture, 10-layer cell factories were seeded, incubated and monitored as described for passage 2, however, up to eight 10-layer cell factories were seeded. The 10-layer cell factories were also harvested on Day 5 or 6 according to confluence and the same criteria for selecting the harvest day was used. For this step HBSS with $5 \%$ heat inactivated AB plasma (HIAB) was used to inactivate the trypsin instead of BMSC CM to reduce residual level of bovine contaminants.

The final product was concentrated and washed thoroughly using a cell washer (Cobe 2991 cell processor). After loading the cells into the cell processor, they were washed for 5 cycles with Plasmalyte A (Baxter Healthcare Corporation, Westlake Village, CA) containing 0.5\% HSA (Fexbumin 25\% (Human) USP, 25\% solution, Baxter Healthcare Corporation). The washed cells were then resuspended in Plasmalyte A with 4\% HSA.

The harvested passage 4 BMSCs were counted manually and assessed for viability by the trypan blue exclusion method, and for safety with endotoxin, sterility, and mycoplasma by PCR analysis. Cell surface marker expression was assessed by flow cytometry. The cells were discarded if they did not meet lot release criteria (Table 1). The number of aliquots of $100 \times 10^{6}$ viable BMSCs that could be cryopreserved was calculated and 
the cells were suspended in a volume of $10 \mathrm{~mL}$ of plasmalyte A with $4 \%$ HSA for each $100 \times 10^{6}$ unit of viable cells.

\section{Cryopreservation and storage}

A total of $10 \mathrm{~mL}$ of BMSCs at $10 \times 10^{6}$ cells per mL were mixed with $10 \mathrm{~mL}$ of freeze mix consisting of $10 \%$ DMSO, 12\% Pentastarch and 8\% Human Serum Albumin (HSA) in plasmalyte A and transferred into customized 20 mL FEP cryobags (AFC Kryosure VP-20f, Gaithersburg, MD, USA). The cells were cryopreserved using a controlled rate freezer (Kryosave, Integra, Planer plc, Sunbury-on-Thames, UK) and stored in the vapor phase of a liquid nitrogen tank. Each cryobag with 100 $\times 10^{6}$ BMSCs was considered a "unit" of BMSCs. A specific label was applied according to ISBT standards.

\section{Quality assurance systems}

A specific software program for capturing cellular therapy data (StemLab, STEMSOFT Software Inc., Vancouver, British Columbia, Canada) was used in the process described above. All components used in the manufacturing process were taken into account and recorded for further tracking: equipment, starting cellular material, ancillary reagents, materials, product inventory, personnel and methods.

\section{Regulatory considerations}

All marrow was collected and BMSCs produced under a NHLBI IRB approved protocol and a DTM, CC, NIH Drug Master File. BMSC products are available for administration to Clinical Center patients who are enrolled in NIH intramural program IRB approved treatment protocols. All patients must also be treated under an Investigational New Drug (IND) application.

\section{Statistical analysis}

The values shown are the mean \pm 1 standard deviation (SD). The correlation coefficients and p-values were calculated by a regression model. The significance between 2 groups was evaluated by student $t$-test. $P<0.05$ was considered significant. All the plots and statistical analysis were completed by using Microsoft Excel 2007.

\section{Results}

Marrow was collected from 10 healthy donors. In order to identify these 10 donors a total of 17 donors were enrolled into the marrow aspiration protocol and were evaluated at our center. Of these 17 potential donors, 6 were found to be ineligible during the screening process and one developed an illness immediately prior to the scheduled donation (Table 2). A 49-year-old male was ineligible because of a history of a prolonged stay in a vCJD risk area, a 31-year-old female because of a low hemoglobin level and a 52-year-old male because of a reactive TTD test. A 26-year-old female was ineligible due to a history of an event that placed her at risk of a TTD, a 30-year-old woman had an elevated PTT result and a 25-year-old female had evidence of an acute CMV infection. A 24-year-old female developed an acute illness the day of the scheduled donation and was not allowed to donate. The remaining 10 donors met donor eligibility criteria and marrow was collected once from 9 donors and twice from one donor, donor 1 . These 10 donors ranged in age from 21 to 67 years and 7 were male (Table 2).

The total volume of aspirated marrow plus media in the 8 syringes obtained from each donor ranged from 21 to $27 \mathrm{~mL}$. The total number of nucleated cells collected was $345 \pm 233 \times 10^{6}$ (mean $1 \pm \mathrm{SD}$ ) and ranged from $127 \times 10^{6}$ to $788 \times 10^{6}$; the average proportion of cells expressing CD34 was $1.35 \pm 0.56 \%$ and ranged $0.45 \%$ to $2.26 \%$. Bone marrow spicules were present in all aspirates except those from donor 4. All marrow aspirate and peripheral blood smears were within normal limits.

For all 11 donations, BMSC colonies were detected in T-75 flasks in the primary culture at day 7. For marrow aspirates from donors 4 and 15, an insufficient number of colonies were detected on day 7 to continue on the culture. For the second marrow aspirate from donor 1, during the culture of BMSCs in 2-layer factories, postdonation information became known that made the donor ineligible and the culture was discarded. The other 8 donations were successfully cultured through passage 4 and the cells were harvested (Table 3 ). The final yield of BMSCs ranged from $990 \times 10^{6}$ to $4760 \times$ $10^{6}$ resulting in 9 to 40 BMSC units. BMSC products from 7 of the 8 donations met all lot release criteria including sterility testing, viability testing, and flow marker analysis (Table 4). The expression of CD34 antigen by BMSCs from donor 15, 5.6\%, exceeded the lot release criteria of $\leq 5 \%$.

In general, TNC and CD34 percentage of marrow cells from younger donors were higher than those from older donors (Figure 1, Panel A), however the correlation was not significant ( $p=0.06$ between age and TNC; $p=$ 0.23 between CD34 percentage and age). Similarly, absolute number of CD34 positive cells tended to be inversely correlated with age ( $p=0.13$, Figure 1 , Panel B). Interestingly, among the 11 collections, the TNC and number of CD34 positive cells collected from the two oldest donors, 59 and 67 years old, were the lowest, and their cells failed to meet colony formation criteria at the end of the primary culture.

We assessed the CFE of the marrow aspirated from each donor. There was a highly significant inverse correlation between CFE and the age of donors $(p=0.01, \mathrm{R}=$ 
Table 2 Characteristics of healthy subjects agreeing to donate marrow for BMSC production and the aspirated marrow

\begin{tabular}{|c|c|c|c|c|c|c|c|c|c|}
\hline \multicolumn{4}{|l|}{ Donor } & \multicolumn{6}{|c|}{ Aspirated Marrow } \\
\hline \multirow[b]{2}{*}{ Number } & \multirow[t]{2}{*}{ Age (years) } & \multirow[b]{2}{*}{ Gender } & \multirow[b]{2}{*}{ Race } & \multirow[t]{2}{*}{ Volume $^{*}(\mathrm{~mL})$} & \multirow[t]{2}{*}{$\operatorname{TNC}\left(10^{6}\right)$} & \multicolumn{2}{|l|}{ CD34 } & \multicolumn{2}{|l|}{ CD3 } \\
\hline & & & & & & $(\%)$ & $\#\left(10^{6}\right)$ & $\%$ & $\#$ \\
\hline 1 & 35.6 & M & AA & 21 & 165 & 2.26 & 3.73 & 10.7 & 17.7 \\
\hline 2 & 22.9 & M & W & 26 & 266 & 1.56 & 4.15 & 11.7 & 31.1 \\
\hline 3 & 22.8 & $\mathrm{~F}$ & W & 27.5 & 374 & 1.20 & 4.48 & 13.3 & 49.7 \\
\hline 4 & 67.9 & $\mathrm{~F}$ & W & 27 & 127 & 0.71 & 0.90 & 5.19 & 6.59 \\
\hline 5 & 21.7 & M & W & 25 & 584 & 0.66 & 3.85 & 7.62 & 44.5 \\
\hline $6+$ & 49.5 & M & W & vCJD risk & NA & NA & NA & NA & NA \\
\hline 7 & 23.7 & $\mathrm{~F}$ & W & 24.8 & 788 & 1.71 & 13.5 & 6.89 & 54.3 \\
\hline $8+$ & 52.1 & M & W & + TTD test & NA & NA & NA & NA & NA \\
\hline $9+$ & 31.5 & $\mathrm{~F}$ & AA & Low Hgb & NA & NA & NA & NA & NA \\
\hline 10 & 27.2 & M & $\mathrm{AA}$ & 27 & 681 & 1.44 & 1.44 & 6.81 & 46.4 \\
\hline 11 & 56.8 & M & W & 26 & 228 & 1.4 & 3.19 & 9.38 & 21.4 \\
\hline $12+$ & 24.9 & $\mathrm{~F}$ & W & Sick & NA & NA & NA & $N A$ & NA \\
\hline $13+$ & 26.6 & $\mathrm{~F}$ & AA & TTD risk & NA & NA & NA & NA & NA \\
\hline $1 \mathrm{t}$ & 36.5 & M & $\mathrm{AA}$ & 25.6 & 153 & 1.99 & 3.04 & 10.4 & 15.9 \\
\hline 14 & 21.3 & M & AA & 27 & 271 & 1.45 & 3.93 & 13.5 & 36.6 \\
\hline 15 & 59.4 & M & W & 25 & 160 & 0.45 & 0.72 & 8.67 & 13.9 \\
\hline 16 & 25.2 & F & W & $+\mathrm{CMV} \operatorname{lgM}$ & NA & NA & NA & NA & NA \\
\hline $17 \dagger$ & 30.8 & $\mathrm{~F}$ & A & Elev. PTT & NA & NA & NA & NA & NA \\
\hline
\end{tabular}

*Volume volume of media plus volume of aspirated marrow

$\dagger$ Ineligible to donate

$\mp$ marrow was collected from donor 1 twice

NA not applicable

$M$ male; $F$ female

$A A$ African American; $W$ White

TTD transfusion transmitted disease

-0.72, Figure 2, Panel A). In addition, the quantity of BMSCs harvested from primary culture tended to decrease when age increased, but the correlation was not significant ( $p=0.07$, Figure 2 , Panel A). The inverse correlation between CFE and age was observed in both female and male donors, and no significance difference in CFE was observed between males and females $(p=$ 0.94, Figure 2, Panel B). Similarly, the quantity of BMSCs in the primary harvest did not differ significantly between males and females ( $p=0.96$, Figure 2, Panel C). Of note, the number of BMSCs from the primary harvest increased as the CFE increased ( $p=0.05$, Figure 2, Panel D).

Among all the potential predictors for BMSC final harvest, the quantity of BMSCs in the primary harvest was the best one. It had a highly significant correlation with quantity of BMSCs in the final harvest ( $p=0.008$, $\mathrm{R}=0.84$, Figure 3, Panel A). The quantity of BMSCs in the final harvest decreased as donor age increased ( $p=$ $0.15, R=-0.56$, Figure 3, Panel B), but was not affected by the marrow aspirate TNC count $(p=0.46$, Figure 3 , Panel C) or CFE ( $p=0.42$, Figure 3, Panel D). However, there was an inverse correlation between quantity of BMSCs in the final harvest and the percentage of CD34 positive cells in the marrow aspirate, although the correlation was not significant $(p=0.11, \mathrm{R}=-0.61$, Figure 3, Panel E).

\section{Discussion}

We established a mechanism to manufacture and store BMSC products from healthy subjects. The BMSC bank was established to support the activity of the NIH Bone Marrow Stromal Cell Transplantation Center which involves the treatment of patients at the NIH Clinical Center who are enrolled in IRB approved treatment protocols. Our banked cells were produced from bone marrow aspirates from healthy subjects, which were plated without removal of red blood cells and expanded using progressively larger plastic surfaces up to passage 4 . Although this restriction on passage number limited the quantity of BMSCs produced, it was chosen based upon data collected in preclinical studies which showed that limiting BMSC expansion to less than 40-50 population doublings minimized growth related senescence. The banked products we manufactured differ from those manufactured at some other centers in that we only produced cells from third party donors rather than both relatives of patients needing BMSC therapy and third 
Table 3 Number of cells harvested, number of population doublings and doubling time for each BMSC passage

\begin{tabular}{|c|c|c|c|c|c|c|c|c|c|c|c|c|c|c|}
\hline \multirow[b]{2}{*}{$\begin{array}{l}\text { Donation } \\
\text { Number }\end{array}$} & \multirow[b]{2}{*}{ Donor } & \multicolumn{2}{|c|}{ T-75 flasks } & \multirow[b]{2}{*}{$\begin{array}{l}\text { Yield } \\
\left(\times 10^{6}\right)\end{array}$} & \multicolumn{2}{|c|}{ 2-layer cells factories } & \multicolumn{3}{|c|}{$\begin{array}{l}\text { First culture in 10-layer cell } \\
\text { factories }\end{array}$} & \multicolumn{3}{|c|}{$\begin{array}{l}\text { Second culture in 10-layer cell } \\
\text { factories }\end{array}$} & \multirow[b]{2}{*}{$\begin{array}{l}\text { Cumulative } \\
\text { Population } \\
\text { Doublings }\end{array}$} & \multirow[b]{2}{*}{$\begin{array}{l}\text { Units in } \\
\text { Storage }\end{array}$} \\
\hline & & CFE & $\begin{array}{l}\text { Yield } \\
\left(\times 10^{6}\right)\end{array}$ & & $\begin{array}{l}\text { Population } \\
\text { Doublings }\end{array}$ & $\begin{array}{l}\text { Doubling } \\
\text { Time (hr) }\end{array}$ & $\begin{array}{l}\text { Yield } \\
\left(\times 10^{9}\right)\end{array}$ & $\begin{array}{l}\text { Population } \\
\text { Doublings }\end{array}$ & $\begin{array}{l}\text { Doubling } \\
\text { Time (hr) }\end{array}$ & $\begin{array}{l}\text { Yield } \\
\left(\times 10^{9}\right)\end{array}$ & $\begin{array}{l}\text { Population } \\
\text { Doublings }\end{array}$ & $\begin{array}{l}\text { Doubling } \\
\text { Time (hr) }\end{array}$ & & \\
\hline W092110086001 & 1 & 6 & 6.5 & 94.4 & 3.9 & 30.9 & 0.81 & 3.2 & 37.3 & 1.73 & 3.4 & 34.9 & 10.5 & 10 \\
\hline W092110086002 & 2 & 18 & 30.3 & 372 & 4.5 & 26.4 & 0.99 & 3.6 & 33 & 2.43 & 3.9 & 30.6 & 12 & 19 \\
\hline W092110086003 & 3 & 9 & 21 & 314.3 & 4.3 & 27.9 & 1.28 & 4 & 30 & 1.61 & 3.3 & 36 & 11.6 & 14 \\
\hline W092110086004 & 4 & 0 & 0.2 & NA & NA & NA & NA & NA & NA & NA & NA & NA & NA & NA \\
\hline W092110086005 & 5 & 11.5 & 52.1 & 456.4 & 4.8 & 24.8 & 1.23 & 3.9 & 30.4 & 4.76 & 4.9 & 24.5 & 13.6 & 40 \\
\hline W092110086006 & 7 & 15 & 28 & 372.5 & 4.5 & 26.4 & 0.9 & 3.5 & 34.3 & 2.17 & 3.8 & 31.9 & 11.8 & 20 \\
\hline W092110086007 & 10 & 1.5 & 25.4 & 255.4 & 4 & 30 & 1.1 & 3.8 & 31.8 & 1.66 & 3.4 & 35.6 & 11.2 & 15 \\
\hline W092111086001 & 11 & 7.5 & 3.9 & 27.9 & 3.9 & 30.9 & 0.15 & 2.9 & 49.8 & 0.99 & 3 & 47.2 & 8.8 & 9 \\
\hline W092111086002 & 1 & 7 & 3.1 & NA & NA & NA & NA & NA & NA & NA & NA & NA & NA & NA \\
\hline W092111086003 & 14 & 5.5 & 12.9 & 233.2 & 4.3 & 28 & 0.97 & 3.6 & 33.3 & 2.52 & 3.98 & 30.2 & 11.9 & 23 \\
\hline W092111086004 & 15 & 4.5 & 2.2 & NA & NA & NA & NA & NA & NA & NA & NA & NA & NA & NA \\
\hline
\end{tabular}

NA not applicable; CFE colony formation efficiency 
Table 4 Characteristics of the 8 lots of BMSCs Produced

\begin{tabular}{llllllllllll}
\hline & \multicolumn{7}{l}{ Biomarker Expression (Percent Reactive Cells) } & & & \\
\cline { 2 - 8 } Donor & CD73 & CD90 & CD105 & CD146 & CD34 & CD45 & CD14 & CD11b & Viability & Sterility & Endotoxin (EU/mL) \\
\hline 1 & 99.0 & 99.0 & 100.0 & 96.9 & 1.6 & 1.7 & 1.0 & 0.9 & 89.0 & No Growth & $<5.0$ \\
2 & 100.0 & 100.0 & 100.0 & 99.5 & 0.5 & 0.6 & 0.1 & 0.6 & 89.0 & No Growth & $<5.0$ \\
3 & 99.8 & 99.7 & 99.8 & 95.1 & 2.3 & 1.2 & 0.2 & 1.1 & 92.0 & No Growth & $<5.0$ \\
5 & 99.9 & 99.9 & 99.9 & 99.9 & 2.2 & 0.9 & 0.7 & 0.9 & 95.0 & No Growth & $<5.0$ \\
7 & 99.8 & 99.8 & 99.8 & 99.6 & 2.2 & 0.8 & 0.6 & 0.8 & 95.0 & No Growth & $<5.0$ \\
10 & 99.7 & 99.7 & 99.8 & 99.7 & 0.9 & 0.9 & 0.6 & 0.9 & 94.0 & No Growth & $<5.0$ \\
11 & 99.4 & 99.4 & 99.7 & 98.9 & 3.4 & 1.2 & 1.4 & 1.6 & 95.0 & No Growth & $<5.0$ \\
14 & 99.6 & 99.6 & 99.7 & 98.9 & 5.6 & 0.5 & 0.1 & 0.5 & 94.0 & No Growth & $<5.0$ \\
\hline
\end{tabular}

party donors $[6,10]$. Our bank also does not include the storage of intermediate products for further manufacture $[9,13,24]$. These intermediary products are thawed and further expanded increasing their time in culture which increases the possibility of producing senescent cells, and a potentially less active final product compared to BMSCs products made up of younger cells $[9,14,25]$.

Our established process allowed for the production of 9 to 40 doses of BMSCs from each donor. The currently approved treatment protocols at our institution involve the treatment of patients two to three times with a dose of 1 to $2 \times 10^{6}$ cells per kg weight. As a result approximately 2 to 9 BMSCs products are needed to treat each patient. Whenever possible each BMSC recipient is given BMSCs from a single donor or lot, so each lot could treat 1 to 20 patients. We have, however, elected to limit the use of each lot to the treatment of 1 to 4 recipients. While all donors meet cell therapy donor criteria and are tested in the same manner as whole blood, platelet apheresis donors and allogeneic cell therapy donors, there is a remote, but real possibility that BMSCs could transmit a pathogen to the recipient. Limiting the number of people treated with each lot limits the number of recipients exposed to a potential pathogen.

We found that the CFE of the aspirated marrow and the quantity of BMSCs in the primary and final harvests were less in older donors. The results are similar to previous studies which found that CFE of marrow preparations was greater in younger subjects [23]. It may be worthwhile to limit the collection of marrow for the production for BMSCs to younger donors, but sufficient data is not yet available to establish an upper age limit. We also found that the quantity of BMSCs in the final harvest was most closely related to the quantity obtained from the primary harvest.

BMSCs produced by our center have several potential advantages over the use of BMSCs from centralized or commercial facilities that produce multiple large lots of BMSCs from a single donor. Our BMSC products are earlier passage cells. The properties of BMSCs change with serial passage. Late passage BMSCs are less potent than early passage BMSCs in several assays. Their proliferation rate is less and their osteogenic and adipogenic differentiation potential is reduced $[26,27]$. When BMSCs are co-cultured with hematopoietic stem and progenitor cells (HPC), early passage BMSCs maintained

(A)

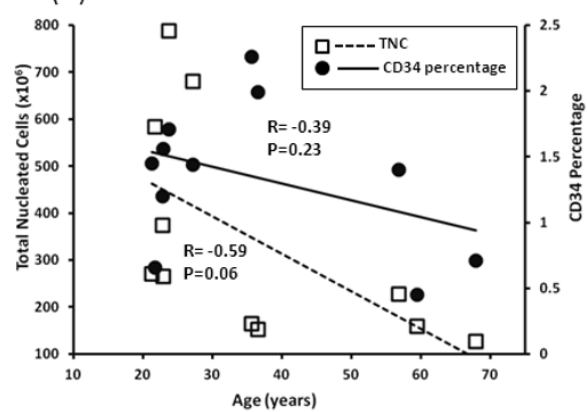

(B)

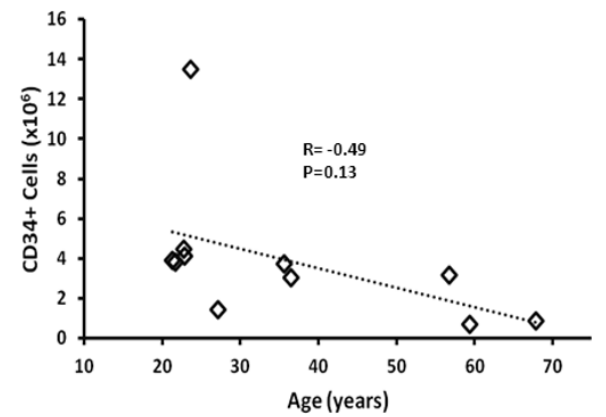

Figure 1 Effects of donor age on the quantity of CD34+ cells and total nucleated cells (TNC) in the aspirated marrow. The relationship between the age of the donor and the quantity of TNCs (Panel A, open squares), percentage of leukocytes expressing CD34 (Panel $\mathbf{A}$, filled circles) and the total number of CD34+ cells in the marrow aspirate (Panel B) are shown. R stands for correlation coefficient and P stands for $\mathrm{P}$ value both of which were calculated using a regression model. 


\section{(A)}
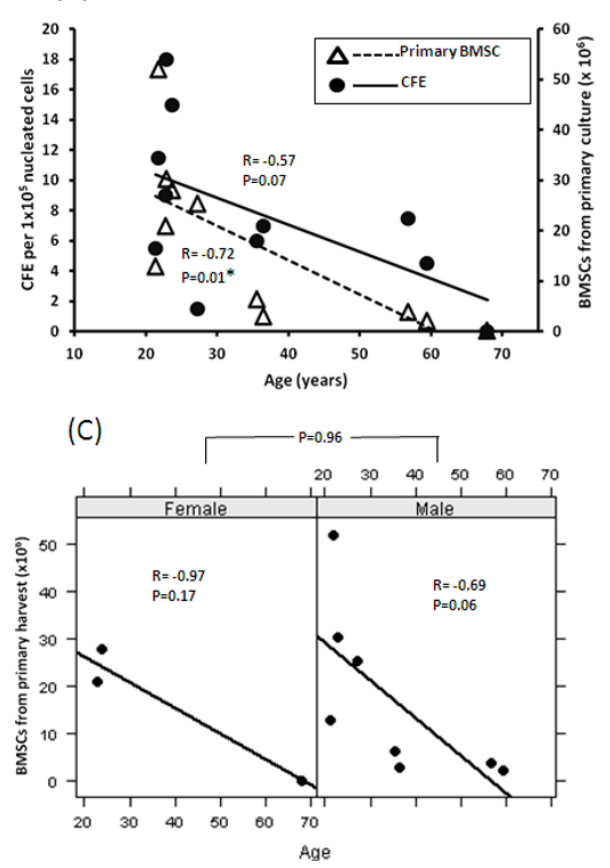

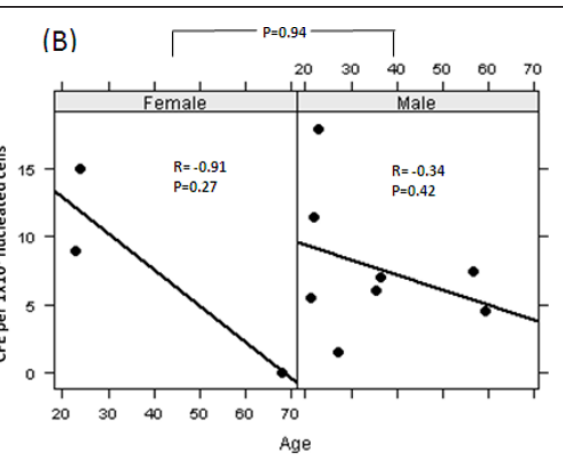

(D)

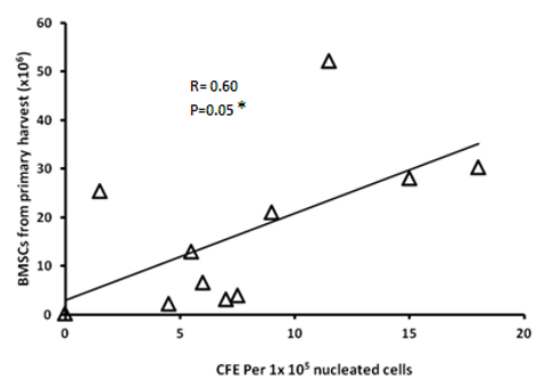

Figure 2 Effect of donor age on the marrow aspirate CFE and the quantity of BMSCs harvested from the primary culture. The relationship between the age of each donor and the CFE of the aspirated marrow (solid circles) and the quantity of BMSCs harvested from the primary culture (open triangles) is shown in panel $\mathbf{A}$. The effects of donor age and gender on the marrow aspirate CFE is shown in panel $\mathbf{B}$ and on the quantity of BMSCS from the primary harvest is shown in panel $\mathbf{C}$. The relationship between marrow aspirate CFE and the quantity of BMSCs from the primary harvest is shown in panel $\mathbf{D}$. R stands for correlation coefficient and $\mathrm{P}$ for $\mathrm{P}$ value. Both were calculated using a regression model. Differences between males and females were compared using t-tests. ${ }^{*}$ indicates significant differences $(p<0.05)$

HPC CD34 antigen expression over more cell divisions than late passage BMSCs [28]. Many studies do not provide detailed information on the production of the BMSCs used in their trials, but BMSC products from one study that successfully treated acute GVHD were passage 1 through 4 cells [10]. Another recent BMSC clinical trial suggested that the survival of therapy resistant acute GVHD patients treated with early passage BMSCs was better than those treated with late passage cells [29]. It is not certain at which passage BMSCs change from an early to late passage phenotype, but it is quite possible that BMSCs produced in large lots and that have undergone 5 or more passages may have begun to acquire a late passage phenotype and may be less effective [25].

There is also considerable evidence of variability in BMSCs due to donor factors. These factors include donor age, inherent inter-donor biological variability and day-to-day intra-donor variability. The use of a large number of BMSC products produced from only 1 or 2 donors could skew the clinical results of BMSC therapy due to donor selection. It could be that all of the BMSC products used for one clinical trial are from a single donor and all BMSC products for another similar clinical trial are from a second donor, but the outcomes of the trials differ because of differences due to donor factors. On the other hand the overall outcomes of clinical trials that make use of multiple lots of BMSC products produced from several different donors are less likely to be effected by variability of individual donor BMSCs.

While BMSCs have been shown to be effective in a number of early phase clinical trials, the critical properties of BMSCs that are responsible for their effectiveness are not known. BMSCs secrete many cytokines and growth factors and many of these may be responsible for the clinical effectiveness of BMSC products. However, it is possible that the mechanisms of action are complex and multiple factors may be responsible for their clinical effectiveness. Furthermore, the factors contributing to clinical effectiveness may vary with disease type. As a result at this time there are no high quality biomarkers for assessing BMSC potency. Due to the lack of good BMSC potency biomarkers we choose to produce BMSCs using techniques that are very similar to those used by other groups whose BMSC products have been shown to be clinically effective; growth in FBS and the use of low passage number cells. Some 
(A)

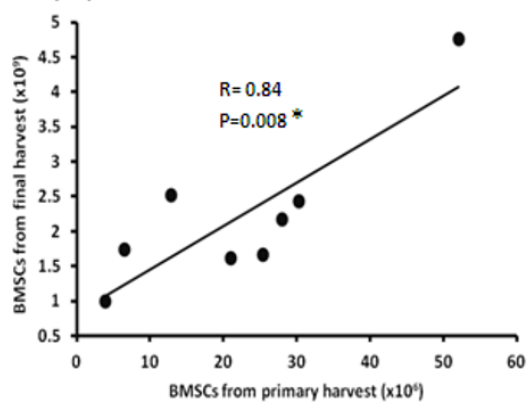

(C)

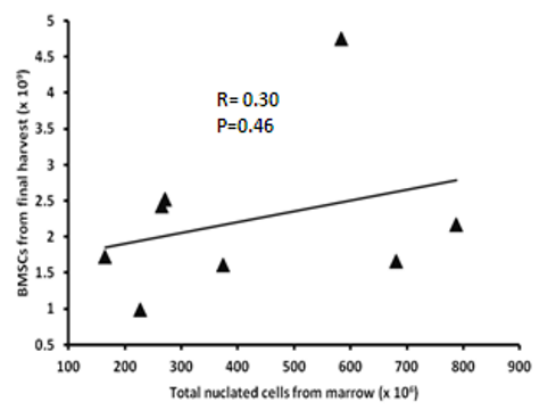

(D)

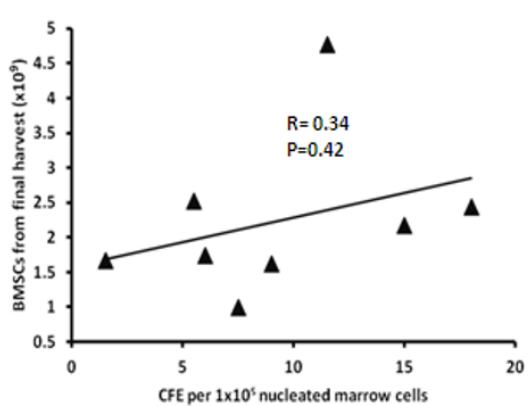

(B)

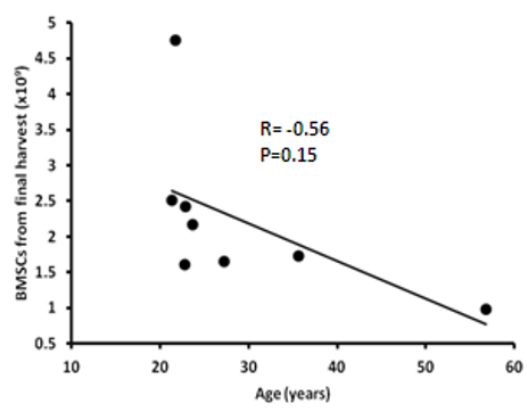

Figure 3 Factors affecting the quantity of BMSCs from the final harvest. The relationship between the quantity of BMSCs from the final harvest and the quantity of BMSCs in the primary harvest are shown in Panel $\mathbf{A}$ and the relationship between BMSCs in final harvest and donor age are shown in Panel $\mathbf{B}$. The effects of the quantity of TNC in the marrow aspirate (Panel $\mathbf{C}$ ), marrow aspirate CFE (Panel $\mathbf{D})$ and percentage of leukocytes expressing CD34 in the marrow aspirate (Panel E) on the quantity of BMSCs in the final harvest are also shown. R stands for correlation coefficient and $\mathrm{P}$ for $\mathrm{P}$ value. Both were calculated using a regression model. ${ }^{*}$ indicates significant differences $(p<0.05)$

other production facilities have elected to use media supplemented with growth factors and cytokines rather than FBS [30,31]. However, it is not clear if these changes in BMSC production techniques will influence their clinical effectiveness.

We found that our cell processing laboratory could scale up, produce and validate BMSC products, but this process is relatively expensive. The use of healthy donors for BMSC production required the development of a number of new procedures and data collection, storage and monitoring systems. These procedures and systems required considerable time and resources to develop. However, producing BMSCs in our institution provides several benefits.

Our donor screening and evaluation, marrow collection and BMSC production process is well defined and highly controlled. By tightly controlling this process we expect to maximize consistency among the lots of BMSC products. This will help minimize variability in clinical outcomes due to lot-to-lot variability.

The use of BMSC products made within our facility permits product analysis and clinical correlation with product characteristics that are critical to the development of new biological therapies. We are storing aliquots from each BMSC lot that will be used clinically to evaluate each lot and compare BMSC properties to clinical outcomes. These studies will likely improve the understanding of the mechanism of action of BMSCs. Commercial manufacturers of BMSC products often do not permit the analysis of their BMSC products by the treating hospital or clinicians. Also, the exact nature of the commercial formulation is not known and there are many concerns on the manufacture of commercial product that may contribute to the less than optimal results. At least one of the commercially available products used bone marrow aspirates from a single unrelated donor to generate millions and millions of cells [13]. In such an instance, it is probable that growth factors were added to BMSC cultures by the company. The addition of growth factors such as fibroblastic growth factor, have been known to result in the loss of a subset of stem cells in bone marrow stromal cells [32]. The enormous number of population "doublings" in the strategy used commercially will result in telomere 
shortening; cells with longer telomeres were found to be critical for the success of adoptive transfer of tumor infiltrating $\mathrm{T}$ lymphocytes in patients with metastatic melanoma [33].

Producing BMSCs at our institution also allows us to modify our production process if an alternative method that results in a more effective product is identified at our institution or at another institution. If we had elected to use cells produced by a commercial laboratory, we would have no control over the production of the cells.

\section{Conclusions}

To our knowledge this is the most comprehensive description of a GMP program at an academic health center to assess third party BMSC donors, aspirate marrow, produce and store BMSC products for clinical use. The GMP production and storage of clinical BMSCs from healthy third party donors is feasible, but is limited by the high number of donors that did not meet eligibility criteria and products that did not meet lot release criteria.

As BMSC therapy matures mechanisms of action will be defined and potency markers identified and the best production method described. At that time for many clinical applications it will likely be best to produce BMSCs at large commercial facilities. However, in this early stage of the development of this field, the production of BMSCs in academic facilities is beneficial and in many ways preferred.

\author{
Acknowledgements \\ We thank the entire staff of the Cell Processing Section of the DTM, Clinical \\ Center for their help with this work and the Bone Marrow Stromal Cell \\ Transplant Center, NIH and DTM, Clinical Center, NIH for their financial \\ support.

\begin{abstract}
Author details
${ }^{1}$ Department of Transfusion Medicine, Clinical Center, National Institutes of Health, Building 10, Room 1C711, Bethesda, MD 20892-1184, USA.

${ }^{2}$ Craniofacial and Skeletal Disease Branch, National Institute of Dental and Craniofacial Research, National Institutes of Health, Bethesda, MD, USA.
\end{abstract}

\section{Authors' contributions}

MS led the development and scale up of the GMP BMSC culture methods, analyzed the data and wrote the manuscript. JR developed and performed the large scale BMSC culture methods, analyzed data, prepared figures and helped write the manuscript. VD-O helped develop GMP culture and processing methods and helped establish clinical BMSC manufacturing. LE developed methods for screening and assessing donors and for collecting marrow. In addition, LE collected the marrow samples, prepared tables and helped write the manuscript. MT led the production of the GMP manufacturing of the BMSC lots. SAK helped with the scale up of the methods for culturing BMSCs and helped write the manuscript. HK helped develop the methods for the GMP manufacturing of BMSCs. AB assisted with the scale up of the BMSC culture methods and helped write the manuscript. MM developed the computer applications for documenting donor eligibility and product manufacturing, storage, release and issue and helped write the manuscript. HGK, PGR and DFS helped with the development of all aspects of the program. DFS also assisted with the marrow collections, analyzed the data and wrote the manuscript. All authors read and approved the final manuscript

\section{Competing interests}

The authors declare that they have no competing interests.

Received: 5 January 2012 Accepted: 6 February 2012

Published: 6 February 2012

\section{References}

1. Friedenstein AJ, Chailakhyan RK, Latsinik NV, Panasyuk AF, Keiliss-Borok IV: Stromal cells responsible for transferring the microenvironment of the hemopoietic tissues. Cloning in vitro and retransplantation in vivo. Transplantation 1974, 17:331-340.

2. Friedenstein AJ, Ivanov-Smolenski AA, Chajlakjan RK, Gorskaya UF, Kuralesova Al, Latzinik NW, Gerasimow UW: Origin of bone marrow stromal mechanocytes in radiochimeras and heterotopic transplants. Exp Hematol 1978, 6:440-444.

3. Horwitz EM, Gordon PL, Koo WK, Marx JC, Neel MD, McNall RY, Muul L, Hofmann T: Isolated allogeneic bone marrow-derived mesenchymal cells engraft and stimulate growth in children with osteogenesis imperfecta: implications for cell therapy of bone. Proc Natl Acad Sci USA 2002, 99:8932-8937.

4. Meuleman N, Vanhaelen G, Tondreau T, Lewalle P, Kwan J, Bennani J, Martiat $P$, Lagneaux $L$, Bron D: Reduced intensity conditioning haematopoietic stem cell transplantation with mesenchymal stromal cells infusion for the treatment of metachromatic leukodystrophy: a case report. Haematologica 2008, 93:e11-e13.

5. Le BK, Rasmusson I, Sundberg B, Gotherstrom C, Hassan M, Uzunel M, Ringden $\mathrm{O}$ : Treatment of severe acute graft-versus-host disease with third party haploidentical mesenchymal stem cells. Lancet 2004, 363:1439-1441.

6. Le BK, Frassoni F, Ball L, Locatelli F, Roelofs H, Lewis I, Lanino E, Sundberg B, Bernardo ME, Remberger M, Dini G, Egeler RM, Bacigalupo A, Fibbe W, Ringden $\mathrm{O}$ : Mesenchymal stem cells for treatment of steroid-resistant, severe, acute graft-versus-host disease: a phase II study. Lancet 2008, 371:1579-1586.

7. Perez Simon JA, Lopez-Villar O, Andreu EJ, Rifon J, Muntion S, ezCampelo M, Sanchez Guijo FM, Martinez C, Lopez D, Del CC: Mesenchymal stem cells expanded in vitro with human serum for the treatment of acute and chronic graft-versus-host disease: results of a phase I/II clinical trial. Haematologica 2011, 96:1072-1076.

8. Zhou H, Guo M, Bian C, Sun Z, Yang Z, Zeng Y, Ai H, Zhao RC: Efficacy of bone marrow-derived mesenchymal stem cells in the treatment of sclerodermatous chronic graft-versus-host disease: clinical report. Biol Blood Marrow Transplant 2010, 16:403-412.

9. Kebriaei P, Isola L, Bahceci E, Holland K, Rowley S, McGuirk J, Devetten M, Jansen J, Herzig R, Schuster M, Monroy R, Uberti J: Adult human mesenchymal stem cells added to corticosteroid therapy for the treatment of acute graft-versus-host disease. Biol Blood Marrow Transplant 2009, 15:804-811.

10. Ringden $O$, Uzunel M, Rasmusson I, Remberger $M$, Sundberg B, Lonnies $H$, Marschall HU, Dlugosz A, Szakos A, Hassan Z, Omazic B, Aschan J, Barkholt L, Le BK: Mesenchymal stem cells for treatment of therapyresistant graft-versus-host disease. Transplantation 2006, 81:1390-1397.

11. Meuleman N, Tondreau T, Ahmad I, Kwan J, Crokaert F, Delforge A, Dorval C, Martiat P, Lewalle P, Lagneaux L, Bron D: Infusion of mesenchymal stromal cells can aid hematopoietic recovery following allogeneic hematopoietic stem cell myeloablative transplant: a pilot study. Stem Cells Dev 2009, 18:1247-1252.

12. Newman RE, Yoo D, LeRoux MA, nilkovitch-Miagkova A: Treatment of inflammatory diseases with mesenchymal stem cells. Inflamm Allergy Drug Targets 2009, 8:110-123.

13. Hare JM, Traverse JH, Henry TD, Dib N, Strumpf RK, Schulman SP, Gerstenblith G, DeMaria AN, Denktas AE, Gammon RS, Hermiller JB Jr, Reisman MA, Schaer GL, Sherman W: A randomized, double-blind, placebo-controlled, dose-escalation study of intravenous adult human mesenchymal stem cells (prochymal) after acute myocardial infarction. J Am Coll Cardiol 2009, 54:2277-2286.

14. Dash NR, Dash SN, Routray P, Mohapatra S, Mohapatra PC: Targeting nonhealing ulcers of lower extremity in human through autologous 
bone marrow-derived mesenchymal stem cells. Rejuvenation Res 2009, 12:359-366.

15. Lee JS, Hong JM, Moon GJ, Lee PH, Ahn YH, Bang OY: A long-term followup study of intravenous autologous mesenchymal stem cell transplantation in patients with ischemic stroke. Stem Cells 2010, 28:1099-1106.

16. Karussis D, Karageorgiou C, Vaknin-Dembinsky A, Gowda-Kurkalli B, Gomori JM, Kassis I, Bulte JW, Petrou P, Ben-Hur T, Abramsky O, Slavin S: Safety and immunological effects of mesenchymal stem cell transplantation in patients with multiple sclerosis and amyotrophic lateral sclerosis. Arch Neurol 2010, 67:1187-1194.

17. Mazzini L, Ferrero I, Luparello V, Rustichelli D, Gunetti M, Mareschi K, Testa L, Stecco A, Tarletti R, Miglioretti M, Fava E, Nasuelli N, Cisari C, Massara M, Vercelli R, Oggioni GD, Carriero A, Cantello R, Monaco F, Fagioli F: Mesenchymal stem cell transplantation in amyotrophic lateral sclerosis: a phase I clinical trial. Exp Neurol 2010, 223:229-237.

18. Venkataramana NK, Kumar SK, Balaraju S, Radhakrishnan RC, Bansal A, Dixit A, Rao DK, Das M, Jan M, Gupta PK, Totey SM: Open-labeled study of unilateral autologous bone-marrow-derived mesenchymal stem cell transplantation in Parkinson's disease. Trans/ Res 2010, 155:62-70.

19. Pal R, Venkataramana NK, Bansal A, Balaraju S, Jan M, Chandra R, Dixit A, Rauthan A, Murgod U, Totey S: Ex vivo-expanded autologous bone marrow-derived mesenchymal stromal cells in human spinal cord injury/ paraplegia: a pilot clinical study. Cytotherapy 2009, 11:897-911.

20. Mankani MH, Kuznetsov SA, Shannon B, Nalla RK, Ritchie RO, Qin Y, Robey PG: Canine cranial reconstruction using autologous bone marrow stromal cells. Am J Pathol 2006, 168:542-550.

21. Kuznetsov SA, Huang KE, Marshall GW, Robey PG, Mankani MH: Long-term stable canine mandibular augmentation using autologous bone marrow stromal cells and hydroxyapatite/tricalcium phosphate. Biomaterials 2008, 29:4211-4216.

22. Horwitz EM, Dominici M: How do mesenchymal stromal cells exert their therapeutic benefit? Cytotherapy 2008, 10:771-774

23. Kuznetsov SA, Mankani MH, Bianco P, Robey PG: Enumeration of the colony-forming units-fibroblast from mouse and human bone marrow in normal and pathological conditions. Stem Cell Res 2009, 2:83-94.

24. Prasad VK, Lucas KG, Kleiner Gl, Talano JA, Jacobsohn D, Broadwater G, Monroy R, Kurtzberg J: Efficacy and safety of ex vivo cultured adult human mesenchymal stem cells (Prochymal) in pediatric patients with severe refractory acute graft-versus-host disease in a compassionate use study. Biol Blood Marrow Transplant 2011, 17:534-541.

25. Allison M: Genzyme backs Osiris, despite Prochymal flop. Nat Biotechnol 2009, 27:966-967.

26. Banfi A, Muraglia A, Dozin B, Mastrogiacomo M, Cancedda R, Quarto R: Proliferation kinetics and differentiation potential of ex vivo expanded human bone marrow stromal cells: implications for their use in cell therapy. Exp Hematol 2000, 28:707-715.

27. Tanabe S, Sato Y, Suzuki T, Suzuki K, Nagao T, Yamaguchi T: Gene expression profiling of human mesenchymal stem cells for identification of novel markers in early- and late-stage cell culture. J Biochem 2008, 144:399-408.

28. Walenda T, Bork S, Horn P, Wein F, Saffrich R, Diehlmann A, Eckstein V, Ho AD, Wagner W: Co-culture with mesenchymal stromal cells increases proliferation and maintenance of haematopoietic progenitor cells. J Cell Mol Med 2010, 14:337-350.

29. von BL, Sundberg B, Lonnies L, Sander B, Karbach $H$, Hagglund $H$, Ljungman P, Gustafsson B, Karlsson H, Le BK, Ringden O: Long-term complications, immunologic effects, and role of passage for outcome in mesenchymal stromal cell therapy. Biol Blood Marrow Transplant 2011, pubmed pmid:21820393.

30. Bernardo ME, Avanzini MA, Perotti C, Cometa AM, Moretta A, Lenta E, Del FC, Novara F, de SA, Amendola G, Zuffardi O, Maccario R, Locatelli F: Optimization of in vitro expansion of human multipotent mesenchymal stromal cells for cell-therapy approaches: further insights in the search for a fetal calf serum substitute. J Cell Physiol 2007, 211:121-130.

31. Goedecke A, Wobus M, Krech M, Munch N, Richter K, Holig K, Bornhauser M: Differential effect of platelet-rich plasma and fetal calf serum on bone marrow-derived human mesenchymal stromal cells expanded in vitro. J Tissue Eng Regen Med 2011, 5:648-654.

32. Sacchetti B, Funari A, Michienzi S, Di CS, Piersanti S, Saggio I, Tagliafico E, Ferrari S, Robey PG, Riminucci M, Bianco P: Self-renewing osteoprogenitors in bone marrow sinusoids can organize a hematopoietic microenvironment. Cell 2007, 131:324-336.

33. Rosenberg SA, Yang JC, Sherry RM, Kammula US, Hughes MS, Phan GQ, Citrin DE, Restifo NP, Robbins PF, Wunderlich JR, Morton KE, Laurencot CM, Steinberg SM, White DE, Dudley ME: Durable complete responses in heavily pretreted patients with metastatic melanoma using T cell transfer immunotherapy. Clin Cancer Res 2011, 17:4550-4557.

doi:10.1186/1479-5876-10-23

Cite this article as: Sabatino et al: The establishment of a bank of stored clinical bone marrow stromal cell products. Journal of Translational Medicine 2012 10:23.

\section{Submit your next manuscript to BioMed Central and take full advantage of:}

- Convenient online submission

- Thorough peer review

- No space constraints or color figure charges

- Immediate publication on acceptance

- Inclusion in PubMed, CAS, Scopus and Google Scholar

- Research which is freely available for redistribution

Submit your manuscript at www.biomedcentral.com/submit 